CZU 327:341.678

https://doi.org/10.52507/2345-1106.2021-2.16

\title{
THE UNITED KINGDOM AND THE EUROPEAN UNION AND THEIR POST-BREXIT TRADE IN HEAVY CONVENTIONAL WEAPONS
}

\author{
ČECH Lubomír, \\ Associate Professor, PhD, CSc, Associate Professor, \\ Head of International Political Relations Department, \\ Faculty of International Relations, \\ University of Economics in Bratislava, Slovak Republic \\ E-mail: lubomir.cech@euba.sk \\ https://orcid.org/0000-0002-8406-9480
}

\section{SUMMARY}

The United Kingdom's withdrawal from the European Union in early 2020 brought new changes and challenges concerning also the heavy conventional weapons trade. Both the UK and the EU now have an opportunity to strengthen their position in the global conventional arms trade and revise territorial structures of their defence industries. The author attempts to analyse the positions of the United Kingdom and the European Union in the global heavy conventional arms trade over the past five years and to outline their future prospects after Brexit. The main source of the paper comes from quantitative data available in world databases monitoring conventional arms transfers as well as the UK's new defence strategy.

Key words: conventional weapons, arms trade, the European Union, the United Kingdom, Brexit.

Introduction. The year 2020 marked an important milestone for the European Union. It was the first time this regional organisation lost one of its members. The United Kingdom ended its EU membership on 31 January 2020. Not only did the EU lose its member state, but it also lost one of its strongest economies, which subsequently affected its status and standing in various international ranking lists. The United Kingdom is one of the most advanced economies also in the field of international trade in conventional weapons. Its two companies, BAE Systems and Rolls-Royce, ranked among top 25 defence and security companies in 2019 [1].

The United Kingdom has to make a decision now about whether to stick to the present territorial and commodity structure of its international trade in conventional weapons or to use new opportunities arising from its withdrawal from the EU. Furthermore, it will have to maintain its status and partnership in conventional arms trade, particularly with respect to its own international trade regulations. The EU member states, especially those which import and export weapons to the United Kingdom, will be affected by Brexit as well. As it happened not so long ago, it is too soon to discuss the effect of the UK's withdrawal on its economy and economies of EU member countries. However, synthesis of several available sources enables analysis of the latest developments, after 2020 in particular, and prognosis of future trends.

Objectives, methods and sources. The purpose of this paper is to analyse the roles the United Kingdom and the European Union have played in the global conventional arms trade in the past five years and to outline their future development prospects after Brexit. The author uses methodology based on the synthesis of quantitative and qualitative data from the Stockholm International Peace Research Institute (SIPRI) database and the United Nations Register of Conventional Arms
(UNROCA). In conclusion, the author uses inductive approach in order to define the main features and future prospects. The data sources also include the document called Global Britain in a Competitive Age: the Integrated Review of Security, Defence, Development and Foreign Policy, the UK's official statistics, the United Nations website as well as papers written by experts who specialize in conventional weapons.

1 Definitions of terms. Integrity of the research presented in this paper requires definition of the term "heavy conventional weapons". From a theoretical perspective, the paper is based on the definition according to which conventional arms "are not weapons of mass destruction" [10]. Conventional weapons are divided into heavy weapons, small arms and light weapons. When defining types of heavy conventional weapons, lots of experts rely upon the Arms Trade Treaty [2] as well as the UNROCA database, which define the following categories of heavy conventional weapons: battle tanks, armoured combat vehicles, large-calibre artillery systems, combat aircraft, attack helicopters, warships, missiles and missile launchers.

The author of the paper uses two global arms transfers' databases, SIPRI and UNROCA, which differ in data collection methods and techniques. The SIPRI database uses the trend-indicator value (TIV), which is "based on the known unit production costs of a core set of weapons and is intended to represent the transfer of military resources rather than the financial value of the transfer" [7]. TIV is a general unit of measurement used for monitoring transfers anywhere in the world. On the other hand, UNROCA monitors quantities of exported and imported conventional weapons.

2 The United Kingdom's Position in the Heavy Conventional Arms Trade. The United States has been the major heavy conventional weapons exporting country for decades. Other large arms exporters include Russia, the leading economies of the European Union and China 
(Graph 1). The European Union as a whole ranked as the second largest exporter between 2016 and 2020 (30,457 million TIV), including the major EU exporting countries, such as France and Germany as well as Spain, Italy, Sweden and the Netherlands, which have expanded their exports in the past two decades.

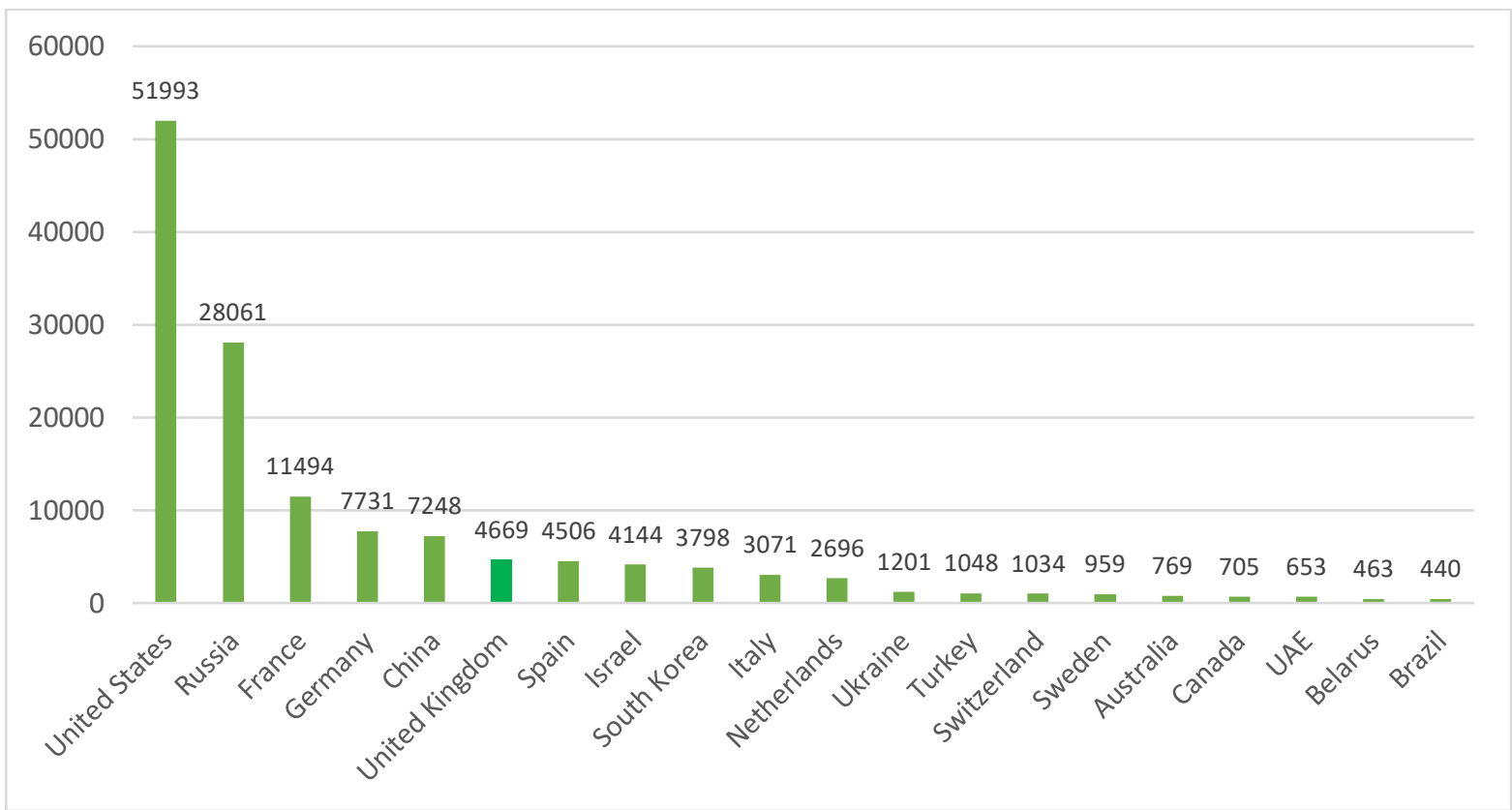

Graph 1. Major exporters of heavy conventional weapons between 2016 and 2020

Source: Author's own graph drawn according to the Stockholm International Peace Research Institute. (2021): TOP LIST TIV TABLES.

The European Union's role as an exporter of heavy conventional weapons will be diminished due to the withdrawal of the United Kingdom, which ranks among top ten exporters (it ranked as the sixth largest exporter between 2016 and 2020 with the volume of exports reaching 4,669 million TIV. The official $U K$ defence and security export statistics for 2019 [5] presented the data according to which the United Kingdom ranked as the second largest arms exporter with defence orders worth $£ 11$ billion. However, some experts considered this figure to be inflated due to the fact that it included collaborative projects between the UK and some European partner countries [3]. Since the European Union and the Russian Federation will have similar volumes of heavy conventional weapons exports, their positions will ultimately depend on foreign policies of individual states, national priorities and global trends in armed conflict. The coronavirus pandemic will probably affect arms export volumes as well owing to prioritisation of resources and decreased production in the military industry.

According to the SIPRI database (Graph 2), exports of heavy conventional weapons from the United Kingdom have been declining. The year 2020, when the UK left the European Union, saw the lowest volumes of exports from this country. However, annual totals (in actual prices) for UK defence exports, including small arms and light weapons, prove an upward trend in values, which were highest in 2018 and 2019 [5]. According to these data, the United Kingdom is the top arms exporter in Europe, except for the Russian Federation.
Maintaining the position of a major conventional arms exporter is not easy as it requires diversification of territorial and commodity structures of a country's foreign trade. The United Kingdom has been criticised several times for its arms exports to countries torn by armed conflicts or to countries which are subject to arms embargoes. For example, the UK exported bombs, missiles and combat aircraft to Saudi Arabia for an officially authorised sales value worth $£ 6.7$ billion in 2015, when the war in Yemen began. According to researchers who examined other official records and accounts, the real value of exports was $£ 20$ billion [9] due to the fact that the official figures did not include sales conducted under the opaque "open licence" system.

The coronavirus pandemic might affect UK's export volumes and its industry as well. As a result, it will be necessary to examine its export values during the upcoming years in order to find out whether the declining trends according to SIPRI will continue and whether Brexit will help boost UK's exports in the form of new trading partners, its own legislation concerning conventional arms trade and its national and foreign policies. Furthermore, it will be necessary to determine the key variables that influenced the value of the country's exports in 2020. Political priorities might increase UK's exports and imports in the future. Some of them are defined in the document entitled Global Britain in a Competitive Age: the Integrated Review of Security, Defence, Development and Foreign Policy, which sets national security as one of its main goals. 


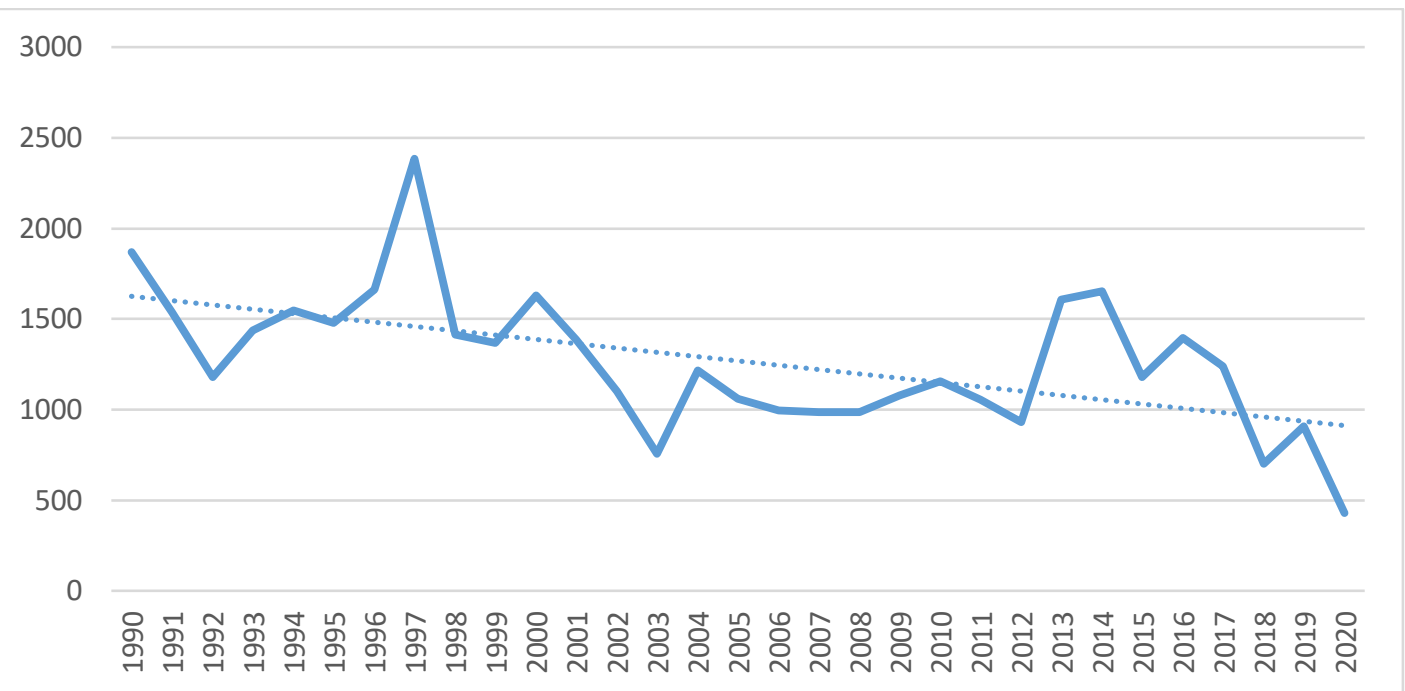

Graph 2. UK exports of heavy conventional weapons after 1990

Source: Author's own graph drawn according to the Stockholm International Peace Research Institute. (2021): IMPORTER/EXPORTER TIV TABLES.

The United Kingdom can be considered as an arms exporting country given absolute values of its heavy conventional weapons trade and the data from the SIPRI [8] database, according to which the UK's exports between 1990 and 2020 were worth 39,319 million TIV and the value of its imports in the same period was 17,121 million TIV, which accounted for $43.54 \%$. Other data which confirm that the UK is a large arms exporter can be found in the UNROCA [11] database, according to which this country reached high values of its exports in all categories of heavy conventional weapons exports. On the other, the values of its imports were low or even zero, especially when it comes to warships, attack helicopters and battle tanks. Nevertheless, the United Kingdom is still a significant importer of conventional weapons. It ranked 14th among global importers of heavy conventional weapons between 2016 and 2020 . However, it reached the highest import values of all the European countries, which were worth 2,886 million TIV (Graph 3). The second highest value among European nations was reached by Italy, which ranked 19th in the global rankings. Obviously, the withdrawal of the United Kingdom from the European Union will weaken its position with regard to heavy conventional arms imports, even more in comparison to its exports.

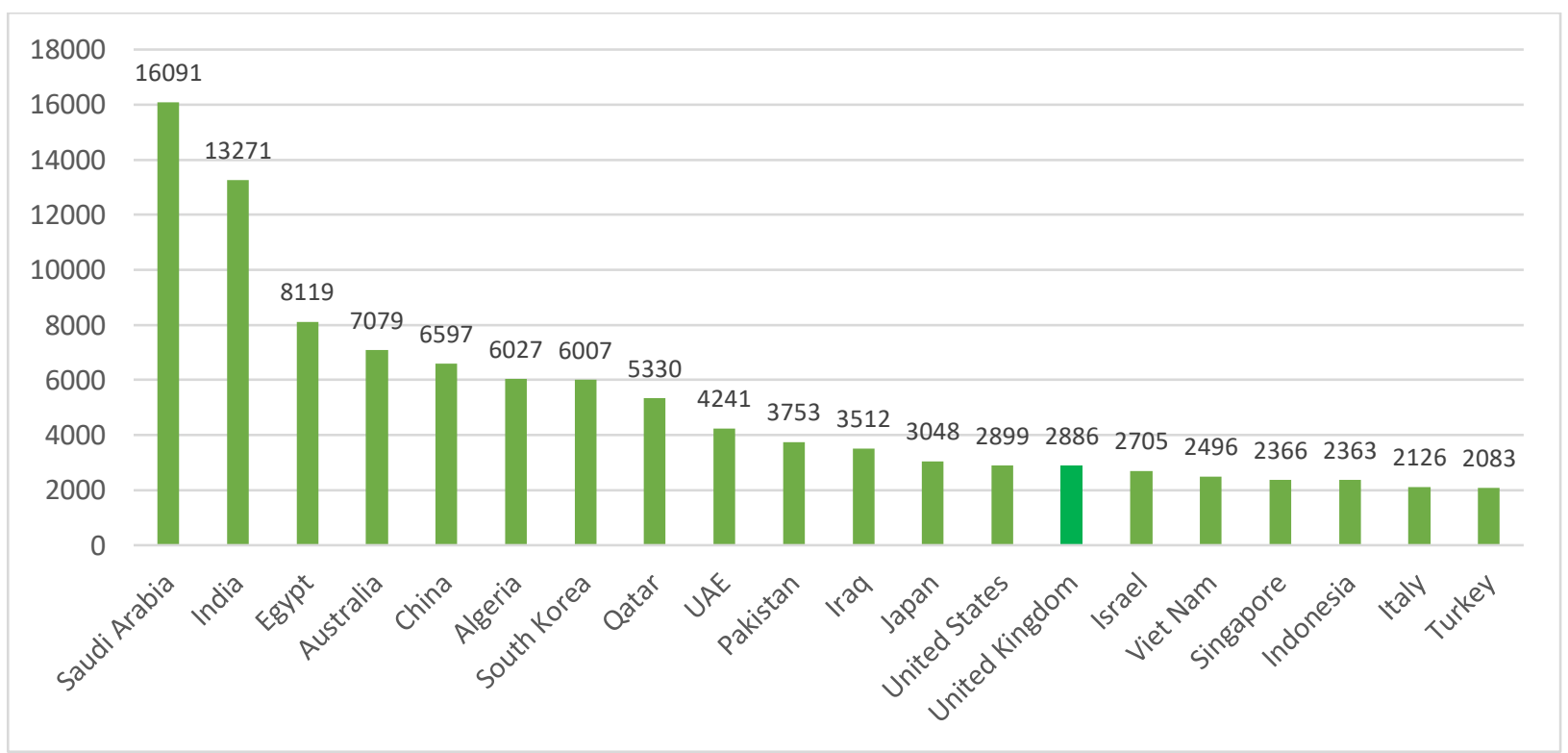

Graph 3. The largest importers of heavy conventional weapons between 2016 and 2020

Source: Author's own graph drawn according to the Stockholm International Peace Research Institute. (2021): TOP LIST TIV TABLES.

The new national strategy, which defines the country's goals, priorities and policies, is highly likely to influence imports of conventional weapons. The United
Kingdom has pledged to continue to meet its NATO commitments and to support its adaptation to security threats in accordance with international law. "It intends 
to increase its defence budget by over $£ 24$ billion over the next four years and remain the largest European spender on defence in NATO. In 2020, the UK's expenditure accounted for $2.2 \%$ of GDP [4]." The United States is the most significant supplier of weapons to the United Kingdom. Brexit will definitely not have negative effects on their relationships. In contrast, it might be a new opportunity. When it comes to the EU countries, the United Kingdom has imported heavy conventional weapons since 2018 especially from major economies and arms producers, such as Germany, Spain, Sweden and the Netherlands. However, the value of these imports was low in comparison to imports from the USA.

Discussion and conclusions. Brexit was an important milestone in the EU's history. It has affected many areas, including the conventional arms trade and both the EU's and the UK's status in the global trade in conventional weapons. As it happened not so long ago, it is impossible to reliably assess its effects on individual economies. However, it is possible to analyse the positions of the United Kingdom and the European Union in the global heavy conventional arms trade in recent years and to outline their future prospects. This paper extends the database of existing publications and points out how important the examined issues are.

The United Kingdom is a significant actor in international trade, particularly when it comes to exports of heavy conventional weapons. It is obvious that its withdrawal from the EU will have negative effects on the position of the European Union in global rankings, including rankings regarding exports and imports of heavy conventional weapons. However, Brexit can also bring new opportunities and changes, especially in the territorial structure of the United Kingdom and the EU member states as well as in volumes of their mutual trade and their trade with third countries. The already difficult situation caused by Brexit has been exacerbated by the COVID-19 pandemic the countries have been facing since 2020.

Besides the coronavirus pandemic, the UK's trade in heavy conventional weapons will be largely affected by its newly signed contracts, its new strategic goals and the global trends in armed conflict, which are of the utmost importance to the country and its trading partners. This key factor, however, poses a threat with regard to the UK's controversial exports to authoritarian regimes and war-torn countries.

The UK's and the EU's future prospects related to the global trade in heavy conventional weapons will require further monitoring and research. In addition, it will be also necessary to focus on attitudes of individual EU member states towards the UK's withdrawal and their mutual trade relationships before and after Brexit, the existence of which has been outlined in this paper.

\section{Bibliographic references:}

[1] ANKEL, S. (2019): From Lockheed Martin to Airbus: These are the 25 largest arms manufacturers in the world. In: Insider. [online] [Accessed 9 September 2021] Retrieved from: <https://www.businessinsider.com/these-are-worlds25-largest-arms-manufacturers-in-the-world-2019-11>

[2] Arms Trade Treaty. (2013): Article 2 - Scope. [online] [Accessed 9 September 2021] Retrieved from: <https://thearmstradetreaty.org/treaty-text.html>

[3] BBC News. (2020): UK remains world's second-biggest arms dealer, figures suggest. [online] [Accessed 8 September 2021] Retrieved from: <https://www.bbc.com/news/uk-54435335>

[4] GOV.UK. (2020): Global Britain in a Competitive Age: the Integrated Review of Security, Defence, Development and Foreign Policy. [online] [Accessed 11 September 2021] Retrieved from: $<$ https://www.gov.uk/government/publications/global-britain-in-a-competitive-age-the-integrated-review-of-securitydefence-development-and-foreign-policy/global-britain-in-a-competitive-age-the-integrated-review-of-securitydefence-development-and-foreign-policy>

[5] GOV.UK. (2020): Official Statistics - UK defence and security export statistics for 2019. [online] [Accessed 8 September 2021] Retrieved from: <https://www.gov.uk/government/statistics/uk-defence-and-security-export-statisticsfor-2019/uk-defence-and-security-export-statistics-for-2019>

[6] Stockholm International Peace Research Institute. (2021): IMPORTER/EXPORTER TIV TABLES. [online] [Accessed 8 September 2021] Retrieved from: 〈https://armstrade.sipri.org/armstrade/page/values.php〉

[7] Stockholm International Peace Research Institute. (2021): Sources and methods. [online] [Accessed 9 September 2021] Retrieved from: 〈https://www.sipri.org/databases/armstransfers/sources-and-methods>

[8] Stockholm International Peace Research Institute. (2021): TOP LIST TIV TABLES. [online] [Accessed 8 September 2021] Retrieved from: 〈https://armstrade.sipri.org/armstrade/page/toplist.php>

[9] STONE, J. (2021): British arms sales to Saudi Arabian regime three times higher than previously thought, investigation finds. [online] [Accessed 9 September 2021] Retrieved from: <https://www.independent.co.uk/news/uk/politics/saudi-arabia-uk-arms-sale-b1884158.html>

[10] United Nations Office of Disarmament Affairs. (n.d.): Conventional Weapons. [online] [Accessed 9 September 2021] Retrieved from: <https://www.un.org/disarmament/conventional-arms/>

[11] United Nations Register of Conventional Weapons. (2021): United Kingdom. [online] [Accessed 8 September 2021] Retrieved from: <https://www.unroca.org/> 